\title{
The Environmental Knowledge Level of Classroom Teaching Students and their Views Toward the Environment
}

\author{
Aysel Özgören \\ MSc. Student, Department of Primary Education, The Faculty of Education, Pamukkale University, Denizli, Turkey \\ Seçil Erökten \\ Associate Professor, Department of Primary Education, The Faculty of Education, Pamukkale University \\ Denizli, Turkey, Corresponding Author Email: erokten@pau.edu.tr
}

\section{Doi:10.5901/mjss.2016.v7n6p159}

\section{Abstract}

\begin{abstract}
Environmental problems that increase day by day can only prevented with an effective environmental education. In order to carry out an effective environmental education a great deal of responsibility lies on teachers and pre-service teachers. Thus, the current study aims to determine the level of environmental knowledge of Classroom Education students and their views toward the environment. The current study adopted a mixed methods design using both qualitative and quantitative analyses. The study was conducted during the 2014-2015 academic year, spring semester. While Pamukkale University, Faculty of Education, Elementary Education Department, Department of Classroom Teaching 50 First-Year students comprised the quantitative study group 7 students comprised the qualitative study group. Firstly the multiple-choice questioned Environmental Knowledge Test was conducted and then consequently interviews were conducted with 7 students. With the scores obtained from the students independent samples t-test and One-way ANOVA analyses were done. When the findings were compared according to gender a statistically significant difference was found in favor of the female students. However, when the data was analyzed according to high school type graduated from and longest time spent living in a site were analyzed no meaningful differences were found. In the qualitative dimension of the research students had difficulties in questions involving human and environment, the ozone layer, greenhouse gas, environmental pollution reasons, the consequences of environmental pollution.
\end{abstract}

Keywords: Environment, environmental issues, environmental awareness, environmental education, environmental knowledge

\section{Introduction}

The environment embodies biological, physical, and chemical factors for all beings (Yıldız, Sipahioğlu and Yılmaz, 2008). Generally, the environment is classified into two groups as natural and artificial environments. Natural environment is defined as the environment that has no human effect and exists by its own naturally whereas artificial environment is defined as the environment that has human effect and the environment created by humans using the natural resources around it (Yıldız, Sipahioğlu and Yılmaz, 2000). The natural environment and the artificial environment have been in balance for centuries and during this balance the environment has never had a negative effect on human life. However, the harm that humans cause to the environment has been increasing to the point that it cannot be ignored. Although at the beginning pollution or similar issues disturbed the people who lived in the current regions in time they turned into bigger issues and added up to a magnitude that affects all human kind (Bozkurt and Cansüngü Koray, 2002). Scientists gathered in 1992 and declared that human behavior harm the nature irreparably and precautions should be taken immediately (Learie, 2009). At the beginning the environmental issues that began as only water, air and soil pollution in time turned into global issues such as climate change, and the thinning of the ozone layer. Hence, nations should take precautions not after these issues get out of hand, but before the environment is destroyed. Thus, national and international authorities should prepare long term plans and should find ways to change people's attitudes towards the environment. The change in an individual's behavior can only be obtained with an effective environmental education. Environmental education is an education that takes place in the natural environment and it is an education that not only aims to understand the environment but also aims to protect it (Çev-Kor, 1999). In 1977 the State Planning Organization in the National Environmental Act Plan stated environmental education as making people aware of their responsibilities and provide solutions to environmental problems by raising environmental awareness (Doğan, 1997). Consequently, environmental education should not only be given to certain sectors but should be given to the whole people in a nation. The environmental education that will be carried out is thought to be given firstly in the child's family and environment and 
then supported by formal education (Tozlu, 1997; Çabuk, 2001). A great deal of responsibility lies on the shoulders of teachers. Because teachers are seen as role models by their students, teachers should act as the role models of their students in order to create sense of responsibility and awareness. Moreover, if academicians emphasize environmental issues and conduct research on what these issues are, how they can be resolved, and what kind of precautions can be taken the research will shed light to teachers and pre-service teachers.

There has been ample number of research done on the topic of environmental issues. For instance, Sadık and Çakan (2010) in their study with university students determined that students who took the environmental education class have higher levels of environmental knowledge and environmental behavior compared to students who did not take the class. Ersoy and Türkkan (2010), observed and investigated the comic strips elementary school students created on their feelings and thoughts about the environmental issues. The study revealed that the students not only addressed global environmental issues such as global warming, the ozone hole but also local issues such as unplanned urbanization. Budak (2008) investigated the environmental education in elementary education programs in Turkey. The study concluded that environmental education is much more effective when started with children at younger ages. Akçay (2006), compared the environmental education given in pre-school education in Turkey with the education given in Canada, the United States, Switzerland, Germany and Japan. The study concluded that the importance given to environmental education is steadily growing in Turkey.

It is important to determine the level of environmental knowledge in students considering that the environmental problems faced today are reaching detrimental levels. The current study aimed to determine the level of environmental knowledge and investigate the relation between the level of environmental knowledge and some variables in Classroom Teaching pre-service teachers. The current study aimed to seek solutions for the following sub-problems:

1. Are there differences in the environmental knowledge levels according to gender in Classroom Teaching preservice teachers?

2. Are there differences in the environmental knowledge levels according to high school type graduated from in Classroom Teaching pre-service teachers?

3. Are there differences in the environmental knowledge levels according to longest time spent living in a site in Classroom Teaching pre-service teachers?

4. What are the views of Classroom Teaching pre-service teachers on environmental issues?

\section{Method}

A mixed methods design was used in the current study. Research methods in which both qualitative and quantitative analysis methods are used are defined as mixed methods design (Creswell, 2003). Verma and Mallick (2005); articulated that mixed methods are widely used, with quantitative methods ample number of participants can be reached and with qualitative methods a more in-depth research can be done. Researchers who prefer a mixed methods design usually prefer different testing types and point scoring scales in their quantitative analyses and interviews, diaries, open ended exam questions, documents in their qualitative (Brannen and Halcomb, 2009). In the current study firstly quantitative data was collected and then the findings were supported with qualitative data. In the quantitative dimension of the current study the survey technique which is included in the scanning model was used. In the qualitative dimension of the current study descriptive method was used.

\subsection{The Study Group}

The current study took place with Bu Pamukkale University, Faculty of Education, Elementary Education Department, Department of Classroom Teaching First-Year students during the 2014-2015 academic year, Spring Semester. The qualitative study group consisted of 7 students and the quantitative sty group consisted of 50 students.

\subsection{Data Collection Tool}

In the current study personal information form and multiple choice knowledge test were used as quantitative data collection tools. "The Environmental Knowledge Test" developed by Bildik (2011) includes topics such as environmental issues, reasons of pollution, consequences of pollution, precautions that need to be taken, recycling, food chain, ecosystem. Bildik (2011) determined the KR-20 reliability coefficient as 0,761 . In order to collect qualitative data semistructured interview form was used. The 5 -item interview questions formed by the researchers were used with the students after expert opinion was taken. 


\subsection{Data Analysis}

In order to check whether the findings of the Environmental Knowledge Test were normally distributed KolmogorovSmirnov analysis was conducted and the results indicated that the data were normally distributed $(Z=1,130 ; p>0,05)$. Parametric tests were also conducted due to normal distribution. The KR-20 reliability coefficient of the test was calculated as 0,649 . The study included 27 female, 23 male, a total of 50 students. 11 of the participants graduated from normal high schools, 1 from a vocational high school, 30 from Anatolian high schools, and 8 from Teacher high schools. When the lengthiest time spent living in a location was investigated 10 lived in big cities, 10 in cities, 15 in provinces, 6 in towns, and 9 in villages.

\section{Results and Discussion}

In order to test whether the Environmental Knowledge Test findings varies according to gender independent samples ttest was conducted. The analysis findings are presented in Table 1.

Table 1: Independent Samples T-Test Findings According to Gender

\begin{tabular}{|l|c|c|c|c|c|}
\hline Gender & N & X & SD & t & p \\
\cline { 1 - 4 } Female & 27 & 18,19 & 2,039 & 2,645 & 0,011 \\
\hline Male & 23 & 16,22 & 3,176 & & \\
\hline
\end{tabular}

As can be seen in Table 1 the mean of the female students was calculated as 18,19, and the mean of the male students as 16,22. The independent samples t-test findings of the Environmental Knowledge Test indicated that there is a significant difference between genders in favor of female students $\left(t_{48}=2,645 ; p<0,05\right)$.

In order to test whether Environmental Knowledge Test findings varied according to high school type graduated from One-Way ANOVA was conducted. The analysis findings are presented in Table 2.

Table 2: One-Way ANOVA Findings of the Environmental Knowledge According to High School Type

\begin{tabular}{|l|c|c|c|c|c|}
\hline Source & Sum of Squares & Degrees of Freedom (df) & Mean Squares & F & p \\
\cline { 1 - 4 } Between Groups & 20,713 & 3 & 6,904 & & \\
\cline { 1 - 4 } Within Groups & 357,367 & 46 & 7,769 & \multirow{2}{*}{0,889} & 0,454 \\
\hline Total & 378,080 & 49 & & & \\
\hline
\end{tabular}

As can be seen in Table 2 the one-way variation analysis showed that there is no statiscial significance between the high school type the students graduated and their environmental knowledge levels $\left(F_{(3,46}=0,831, p>0,05\right)$.

In order to test whether Environmental Knowledge Test findings varied according to the longest time spent living in a site One-Way ANOVA was conducted. The analysis findings are presented in Table 3.

Table 3: One-Way ANOVA Findings of the Environmental Knowledge According to Longest Time Spent Living in a Site

\begin{tabular}{|c|c|c|c|c|c|}
\hline Source & Sum of Squares & Degrees of Freedom (df) & Mean Squares & $F$ & $p$ \\
\hline Between Groups & 5,413 & 4 & 1,353 & \multirow{3}{*}{0,163} & \multirow{3}{*}{0,956} \\
\hline Within Groups & 372,667 & 45 & 8,281 & & \\
\hline Total & 378,080 & 49 & & & \\
\hline
\end{tabular}

As seen in Table 3, the one-way variation analysis between longest time spent living in a site and environmental knowledge level showed no statistical significance according to 0,05 significance level $(F(4,45)=0,124, p>0,05)$.

When the percentage values of the questions correctly answered in the test were analyzed it was determined that the correct answers varied between $14 \%$ to $96 \%$. The analysis revealed that the percentage of the correct answers were lower in some questions compared to other questions. The questions that had low percentage correct answers with their percentages were as follows:

- The 3'rd question in which students were asked to explain the place of humans and the relationship between humans and other beings in nature; $54 \%$ of the students answered correctly, 
- The 13 'th question in which students were asked what the effects of the thinning of the ozone layer caused by environmental pollution on future living beings life are not; $34 \%$ of the students answered correctly,

- The 18'th question in which students were asked what could be done to prevent greenhouse gas oscillation, $14 \%$ of the students answered correctly making this answer the lowest percentage

- The $20^{\prime}$ th questing involving the reasons of environmental pollution, $58 \%$ of the students answered correctly,

- The 23'rd question in which students were asked the common characteristics of the catastrophic events on earth, $20 \%$ of the students answered correctly.

When the interview answers with the 7 students from the Classroom Teaching Department are analyzed:

The first student interviewed indicated that s/he saw the trash thrown on the ground and no recycling done as environmental issues and also added that people were ignorant about these topics. S/he added that as precautions against these issues s/he threw plastics into recycling bins and tried not to throw trash on the ground. S/he also added that s/he felt sorry because when s/he hears about an environmental issue s/he thinks that people did not only harm themselves but also the whole community and the nature. The student depicted that s/he paid attention not to use deodorant and throw trash on the ground as precautions. When asked whether s/he had a solution recommendation s/he said that visuals were more lasting for people and thus environmental issues should be delivered through posters and moreover, environmental education should be given in schools along with visuals.

The second student interviewed indicated that s/he saw environmental pollution and nuclear energy as environmental problems. S/he added that as precautions she tried not to throw trash on the ground and tried to recycle and also felt that as if her/his own house was being soiled and felt sad when s/he hears about any kind of environmental issue. When asked if $\mathrm{s} / \mathrm{he}$ had a solution for environmental issues s/he said that instead of nuclear energy edible energy sources should be preferred.

The third student interviewed indicated that s/he saw global warming and sea pollution as environmental issues. As precautions, s/he indicated that s/he did not use deodorant, gave importance to recycling and if awareness were increased it would be effective in preventing environmental pollution.

The fourth student interviewed indicated that s/he saw air, noise and traffic pollution as environmental issues. If environmental issues were not prevented they would pass from generation to generation and this situation upset her/him, thus s/he tried not to throw trash on the ground. S/he also indicated that in order to prevent environmental issues awareness should be enforced not by rules but in a fun way.

The fifth student interviewed indicated that s/he saw polluting the environment insensibly as the main environmental issue. S/he exemplified throwing trash on the ground, using water resources insensibly, air pollution, no recycling, as the main environmental issues. S/he also depicted that when faced with any kind of environmental problem like when s/he saw a person throwing trash on the ground s/he warned the person, s/he collected blue lids and awareness should be raised, and s/he separated the type of trash for recycling.

The sixth student interviewed indicated that s/he saw the trash thrown on the ground and global warming as environmental issues. In order not to pollute the environment s/he did not throw trash on the ground and did not take too many precautions because according to her/him the biggest issue was throwing trash on the ground. S/he also said that if awareness was raised then environmental issues could be resolved.

The seventh student interviewed indicated that s/he saw global warming and no recycling as environmental issues. S/he indicated that s/he was sensitive about recycling and did not use deodorant. S/he also depicted that s/he was worried about future environmental issues and hence s/he was member of organizations that deal with environmental issues and actively participated in the events. S/he also thinks that raising awareness in people would resolve environmental issues.

\section{Conclusion}

The current study investigated the background information of Classroom Teaching First-year students on environmental issues using a quantitative measurement tool, The Environment Knowledge Test, and also tested whether gender, high school type graduated from and longest time spent living in site changed the outcomes. When the gender variable was investigated a statistically significant difference was found in favor of the female students. In the literature various research studies indicate statistically significant differences in female students; the current study found similar findings as well (Sargın, et al. 2016; Demircioğlu, Demircioğlu and Yadigaroğlu, 2015; Ahi and Özsoy, 2014). There were no statistical significances found when looked at high school type graduated from or longest time spent living in a site. It could be said that high school type graduated from or longest time spent living in a site do not have effects on in the 
students' environmental knowledge or awareness. Şama (2003), in the study with university students determined that the female students had a more positive attitude toward the environment compared to the male students, there were no significant differences between first-year and fourth-year university students; however, the attitude varied according to the department of the student. It was observed that students whose fathers have higher education levels and students whose fathers have highly esteemed occupations had a more positive attitude toward the environment, but the site these students lived in did not have an effect on their attitude. Incekara and Tuna (2010), aimed to determine the level of knowledge of environmental problems of middle school students. Their study revealed that students did not know some of the concepts and did not have enough knowledge to be able to explain some of the concepts.

The percentage of the correct answers to the Environmental Knowledge Test conducted in the current study revealed that some of the questions had low percentage levels. The students had difficulties with the questions that involved human and the environment, the ozone layer, the greenhouse gas, the reasons for environmental pollution, the consequences of environmental pollution. As the result of the interviews conducted, it was determined that the students did not have any opinions on the subject matters. The students indicated issues such as recycling, trash thrown on the ground and unawareness about the environment. Moreover, some students mentioned topics such as nuclear energy and global warming. Most of the students depicted that they were careful about using deodorant but could not offer an explanation on how deodorant affects the ozone layer. As a result of the current study it was established that the students were sensitive toward the environment but due to the insufficiency of their background information they cannot take deliberate action and precautions. It can be said that because the study group have not yet received the environmental education class they do not have enough knowledge and awareness on the topic. Hence, it would be beneficial to repeat the current study after these students take the environmental education class.

\section{References}

Ahi, B. ve Özsoy, S. (2015). Illkokullarda Görev Yapan Öğretmenlerin Çevreye Yönelik Tutumlarl: Cinsiyet ve Mesleki Kıdem Faktörü, Kastamonu Eğitim Dergisi, 23, 1, 31-56

Akçay, İ. (2006). Farkı Ülkelerde Okul Öncesi Öğrencilerine Yönelik Çevre Eğitimi. Uludağ Üniversitesi, Sosyal Bilimler Enstitüsü, Illköğretim Anabilim Dalı, Yüksek lisans tezi, Bursa.

Bozkurt, O. ve Cansüngü Koray, Ö. (2002). IIlköğretim Öğrencilerinin Çevre Eğitiminde Sera Etkisi ile İlgili Kavram Yanılgıları. Hacettepe Üniversitesi Ë̆itim Fakültesi Dergisi, 23, 67-73.

Brannen, J. and Halcomb, E. J. (2009). Data collection in mixed method research. In S. Andrew \& E. J. Halcomb (Eds.), Mixed methods research for nursing and the healt sciences, UK: Willey Blackwell.

Budak, B. (2008). Illköğretim Kurumlarında Çevre Eğitiminin Yeri ve Uygulama Çalışmaları. Ege Üniversitesi, Fen Bilimleri Enstitüsü, Yüksek lisans tezi, İzmir.

Creswell, J. W. (2003). Research Design: qualitative, quantitative, and mixed methods approaches (2ndEd.). CA: Sage Publications.

Çabuk, B. (2001). Okulöncesi dönem çocuklarının çevre ile ilgili farkındalık düzeyleri. Ankara Üniversitesi, Fen Bilimleri Enstitüsü, Yüksek Lisans Tezi, Ankara.

Çev-Kor, Çevre Koruma ve Araşıırma Vakıı (1999). Okul öncesi çevre eğitimi, Çevre Eğitimi Merkezi Yayınları, İzmir.

Çimen, O. (2013). Dönüşümsel öğrenme kuramına dayalı çevre eğitiminin biyoloji ögretmen adaylarının çevre sorunlarına yönelik algılarına etkisi. Gazi Üniversitesi, Eğitim Bilimleri Enstitüsü, Doktora Tezi, Ankara.

Demircioğlu G., Demircioğlu H. ve Yadigaroğlu M. (2015). Fizik, Kimya ve Biyoloji Öğretmen Adaylarının Çevre Bilinç Düzeylerinin Değerlendirilmesi, Adıyaman Üniversitesi, Sosyal Bilimler Enstitüsü Dergisi, 8, 19, 167- 193.

Doğan, M. (1997). Ulusal çevre eylem planı: Eğitim ve Katıım, Devlet Planlama Teşkilatı, Ankara.

Ersoy, A. F. ve Türkkan, B. (2010). Illköğretim Öğrencilerinin Çizdikleri Karikatürlere Yansıttıkları Sosyal Ve Çevresel Sorunların Incelenmesi, Education And Science, 35 (156), 96-109.

İncekara, S. ve Tuna, F. (2010). Ortaöğretim Öğrencilerinin Çevresel Konularla İlgili Bilgi Düzeylerinin Ölçülmesi: Çankırı Ili Örneği. Marmara Coğrafya Dergisi, Sayı: 22, 168 - 182.

Learie, S. (2009). Changing Lives, Creating Leaders: Transformational Environmental Education. Master's thesis, Royal Roads University, Canada.

Sadık, F. ve Çakan, H. (2010). Biyoloji Bölümü Öğrencilerinin Çevre Bilgisi ve Çevre Sorunlarına Yönelik Tutum Düzeyleri. Ç.Ü. Sosyal Bilimler Enstitüsü Dergisi, 19, 1, 351-365.

Sargın, S.A., Baltacı, F., Katipoğlu, M., Erdik, C., Arbatlı, M.S., Karaardıç, H., Yumuşak, A. ve Büyükcengiz, M. (2016). Öğretmen adaylarının çevreye karşı bilgi, davranış ve tutum düzeylerinin araş̧ııııması, Education Sciences (NWSAES), 11(1): 1-22.

Şama, E. (2003). Öğretmen adaylarııın çevre sorunlarına yönelik tutumları, Gazi Üniversitesi, Eğitim Fakültesi Dergisi, 23, 2, 99-110.

Tozlu, A. (1997). İlkokul çağındaki çocukların çevre sağı̆̆ı bilgileri ve etkileyen faktörler. Hacettepe Üniversitesi, Sağlık Bilimleri Enstitüsü, Yüksek Lisans Tezi, Ankara.

Verma, G. K. and Mallick, K. (2005). Researching education: Perspectives and techniques. London: Falmer Press.

Yıldız, K., Sipahioğlu, Ş. ve Yılmaz, M. (2000). Çevre Bilimi, Gündüz Eğitim ve Yayıncılık, Ankara

Yıılız, K., Sipahioğlu, Ş. ve Yılmaz, M. (2008). Çevre Bilimi ve Eğitimi, Gündüz Eğitim ve Yayınclık, Ankara. 
ISSN 2039-2117 (online)

ISSN 2039-9340 (print)
Mediterranean Journal of Social Sciences MCSER Publishing, Rome-Italy
Vol 7 No 6 November 2016 